\section{Prestorage Heat Treatment and Poststorage Quality of Mango Fruit}

\author{
Saichol Ketsa \\ Department of Horticulture, Faculty of Agriculture, Kasetsart University, \\ Chatuchak, Bangkok 10900, Thailand
}

Sugunya Chidtragool

Yasothon Agricultural and Technological College, Amphur Muang, Yasothon 35000, Thailand

\author{
Susan Lurie ${ }^{1}$ \\ Department of Postharvest Science, ARO, The Volcani Center, Bet Dagan \\ 50250, Israel
}

Additional index words. Mangifera indica, ripening, chilling injury

\begin{abstract}
Freshly harvested mango fruit (Mangifera indica L. cv. Nam Dok Mai), were heated at $38{ }^{\circ} \mathrm{C}$ for 3 days or heated and then stored at $4{ }^{\circ} \mathrm{C}$ for 3 weeks before ripening at $25^{\circ} \mathrm{C}$, then compared with nonheated fruit for quality changes. When not refrigerated, heated and nonheated fruit ripened within 7 days to a comparable quality, although titratable acidity remained higher in heated fruit. The peel of heated fruit was initially yellower in cold-stored fruits, and soluble solids content was initially greater, whereas firmness and titratable acidity were less than that of nonheated fruit during ripening at 25 ${ }^{\circ} \mathrm{C}$. After cold storage and ripening, heated fruit had a lower incidence of disease and developed less chilling injury than nonheated fruit. Nonheated fruit stored at $4{ }^{\circ} \mathrm{C}$ also developed off-flavors whereas the heated fruit did not. Heat treatment did not inhibit ripening but did ameliorate low-temperature injury.
\end{abstract}

Mango, like other tropical fruits, has a short shelf life when held at ambient temperatures and is sensitive to chilling injury when stored below $10{ }^{\circ} \mathrm{C}$ (Lizada et al., 1984). Symptoms of chilling injury, including pitting, discoloration, internal browning, uneven ripening, off-flavors, and increased incidence of decay, can all develop in fruit after removal from chilling temperatures and lead to poor overall quality (Paull, 1990).

A $38^{\circ} \mathrm{C}$ postharvest heat treatment can inhibit ripening of tomato (Lycopersicon esculentum Mill.) fruit (Lurie et al., 1996) by inhibiting the synthesis of the enzymes involved in the ripening processes, including those involved in ethylene synthesis and fruit softening. This inhibition is removed once the temperature is lowered. In addition, a postharvest heat treatment applied prior to low-temperature storage can reduce the incidence of chilling injury in cold-sensitive fruits, such as avocado (Persica america Mill.) (Woolf et al., 1995), mango (McCollum et al., 1993), persimmon (Diospyros kaki L.F.) (Lay-Yee et al., 1997; Woolf et al., 1997), and tomato (Lurie and Klein, 1991). Heat treatments, with both hot air and hot water, can also be used for

Received for publication 7 Jan. 1999. Accepted for publication 21 June 1999. The research was financially supported by the German-Israeli Agricultural Research Agreement (GIARA), No. E-140. The cost of publishing this paper was defrayed in part by the payment of page charges. Under postal regulations, this paper therefore must be hereby marked advertisement solely to indicate this fact.

${ }^{1}$ To whom reprint requests should be addressed; email: slurie@agri.gov.il; fax: 972-3-9683622. disinfestation (Lurie, 1998). In the latter case, pretreatments of moderate heat, such as $38^{\circ} \mathrm{C}$, induce tolerance of fruit to the higher temperatures necessary to kill insects (Joyce and Shorter, 1994; Woolf and Lay-Yee, 1997).

The objective of this study was to determine if heat treatment at $38^{\circ} \mathrm{C}$ would improve the quality of mango fruits that are stored at low temperature to prolong their postharvest life.

\section{Material and Methods}

Mango (cv. Nam Dok Mai) fruit were harvested in Thailand at commercial maturity (110 $\pm 3 \mathrm{~d}$ after fruit set) and brought to the laboratory within a day. Fruit were selected for uniformity of shape, size, and color, and any blemished or diseased fruit were discarded. Fruit were divided into four groups. One group was held at $25^{\circ} \mathrm{C}, 75 \%$ relative humidity $(\mathrm{RH})$ for ripening, and one at $4{ }^{\circ} \mathrm{C}, 98 \% \mathrm{RH}$ storage for 3 weeks before transfer to $25^{\circ} \mathrm{C}$ for ripening. The other two groups were held in a chamber at $38{ }^{\circ} \mathrm{C}, 60 \% \mathrm{RH}$ for $3 \mathrm{~d}$. Trays of water were placed on the chamber floor and each plastic basket containing 15 fruit was covered with a plastic bag to retard weight loss. To avoid the generation of modified atmospheres, the bags were not closed. At the end of $3 \mathrm{~d}$, one group of fruit was removed to $25^{\circ} \mathrm{C}$ for ripening, and the other was placed at $4{ }^{\circ} \mathrm{C}$ storage for 3 weeks and then at $25^{\circ} \mathrm{C}$.

Peel and pulp color, firmness, soluble solids content (SSC), titratable acidity (TA), disease incidence, chilling injury (CI), and offat $25^{\circ} \mathrm{C}$. Peel color was measured with a color flavors of fruit were measured during ripening difference meter (Tricolor LFM 3, Berlin) at the midsection of the fruit, and the " $b$ " value was recorded as an indication of the development of pigmentation in this yellow cultivar. Pulp firmness was determined with an Effegi (Hatfield, Pa.) firmness tester (0.5-cm tip) on opposite, pared sides of the fruit. Soluble solids content and TA were measured on expressed juice from sections of the fruit; the former was determined with a hand refractometer (Atago, Tokyo) and the latter by titrating the juice with $0.01 \mathrm{~N} \mathrm{NaOH}$ to a $\mathrm{pH}$ of 8.2 and calculating the result as citric acid. Fruit decay and CI were scored on a scale of 1 to 4 based on the extent of fruit surface area affected, where $1=$ healthy, $2=$ up to $25 \%, 3=$ up to $50 \%$, and $4=>50 \%$ of the fruit area affected. Flavor was also assessed using a scale of 1 to 4 where $1=$ normal flavor, $2=$ mild, $3=$ moderate, and $4=$ high levels of offflavor.

The data represent the means for four replications, with each treatment containing 15 fruit. Bars on the figures represent the standard deviation of means. The experiment was repeated three times in different seasons with comparative results, but data for only one replicated experiment are presented.

\section{Results}

Nonheated mangoes cold-stored for 3 weeks at $4{ }^{\circ} \mathrm{C}$ developed moderate $\mathrm{CI}$ during poststorage ripening (Fig. 1A). The symptoms were blackened lenticels (pitting) and grayish
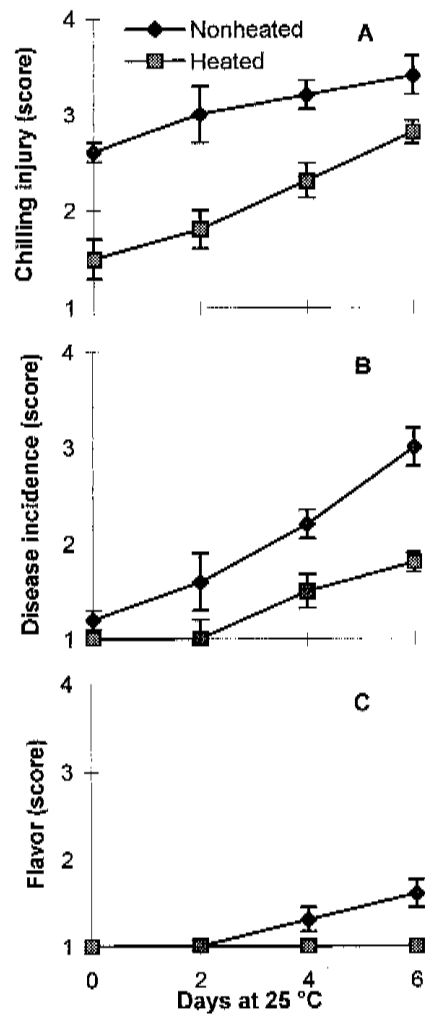

Fig. 1. (A) Chilling injury, (B) surface decay, and (C) off-flavors in nonheated or heated mangoes following 3 weeks of storage at $4{ }^{\circ} \mathrm{C}$. Fruit were scored from 1 (healthy) to 4 (severely affected). Vertical bars indicate standard deviation. 
patches on the peel. On removal from cold storage, CI was apparent on the nonheated fruit and increased in severity during ripening. The heated fruit showed almost no CI on removal, but there was some development of CI during $6 \mathrm{~d}$ at $25^{\circ} \mathrm{C}$. Decay was also apparent on the nonheated fruit on removal from cold storage (Fig. 1B), and increased rapidly during ripening; this was primarily anthracnose, caused by Colletotrichum gloeosporioides Penz. Heated fruit were decay-free through the second day of ripening, but by the fourth day some lesions appeared. Decay severity at the end of the ripening period was much less on heated than on nonheated fruit. On fruit not cold-stored, decay began to appear after $4 \mathrm{~d}$ of ripening as well, and after $6 \mathrm{~d}$ the score was 1.5 for both heated and nonheated fruit (data not shown). There were no off-flavors in fruit not coldstored (data not shown), or in fruit that were heat-treated and cold-stored (Fig. 1C). However, in nonheated fruit after cold storage, off flavors were apparent after $4 \mathrm{~d}$ of ripening.

Fruit softened during the $3 \mathrm{~d}$ at $38^{\circ} \mathrm{C}$ from $70 \mathrm{~N}$ (the freshly harvested fruit) to $48 \mathrm{~N}$ (Fig. 2A). However, the nonheated fruit had softened to $25 \mathrm{~N}$ after $2 \mathrm{~d}$ at $25{ }^{\circ} \mathrm{C}$. During cold storage, the heated fruit softened more than the nonheated fruit and were $65 \%$ softer on removal (Fig. 2B). This indicates a good deal of softening during cold storage. However, during the first $2 \mathrm{~d}$ at $25^{\circ} \mathrm{C}$ no change occurred in firmness of heated, cold-stored fruit, whereas nonheated, cold-stored fruit softened. After 6 d at $25^{\circ} \mathrm{C}$ there was no difference in firmness among any of the treatments.

The peel became yellower as the fruit ripened at $25{ }^{\circ} \mathrm{C}$, as well as during the heat treatment (Fig. 2C). Heated fruit developed a yellow peel at a rate similar to that of nonheated, non-cold-stored fruit. During cold storage the heated fruit progressed in peel color development, and at removal were yellower than nonheated fruit. However, by day 4 at $25{ }^{\circ} \mathrm{C}$ fruit from both treatments had reached their maximum yellow color (Fig. 2D).

Heating did not affect the SSC of fruits not cold-stored (Fig. 3A). Heated fruit had a higher SSC after cold storage; however, by the fourth day at $25^{\circ} \mathrm{C} \mathrm{SSC}$ was similar in fruit from all treatments (Fig. 3B). In contrast, heating slowed the loss of TA during ripening without cold storage (Fig. 3C). After cold storage, however, the TA of heated fruit was $50 \%$ less than that of nonheated fruit (Fig. 3D). Again, by day 4 TA was similar in fruit from all treatments.

\section{Discussion}

Heat treatment at $38^{\circ} \mathrm{C}$ did not inhibit the ripening of 'Nam Dok Mai' mango fruit during ambient or cold storage. This contrasts with other studies showing inhibition of ripening in both temperate fruits, such as apple (Malus $\times$ domestica Borkh.) (Lurie and Klein, 1990), and subtropical fruits, such as tomato (Lurie and Klein, 1992). Inhibition might have occurred if the treatment temperature had been higher. Growing conditions can affect fruit
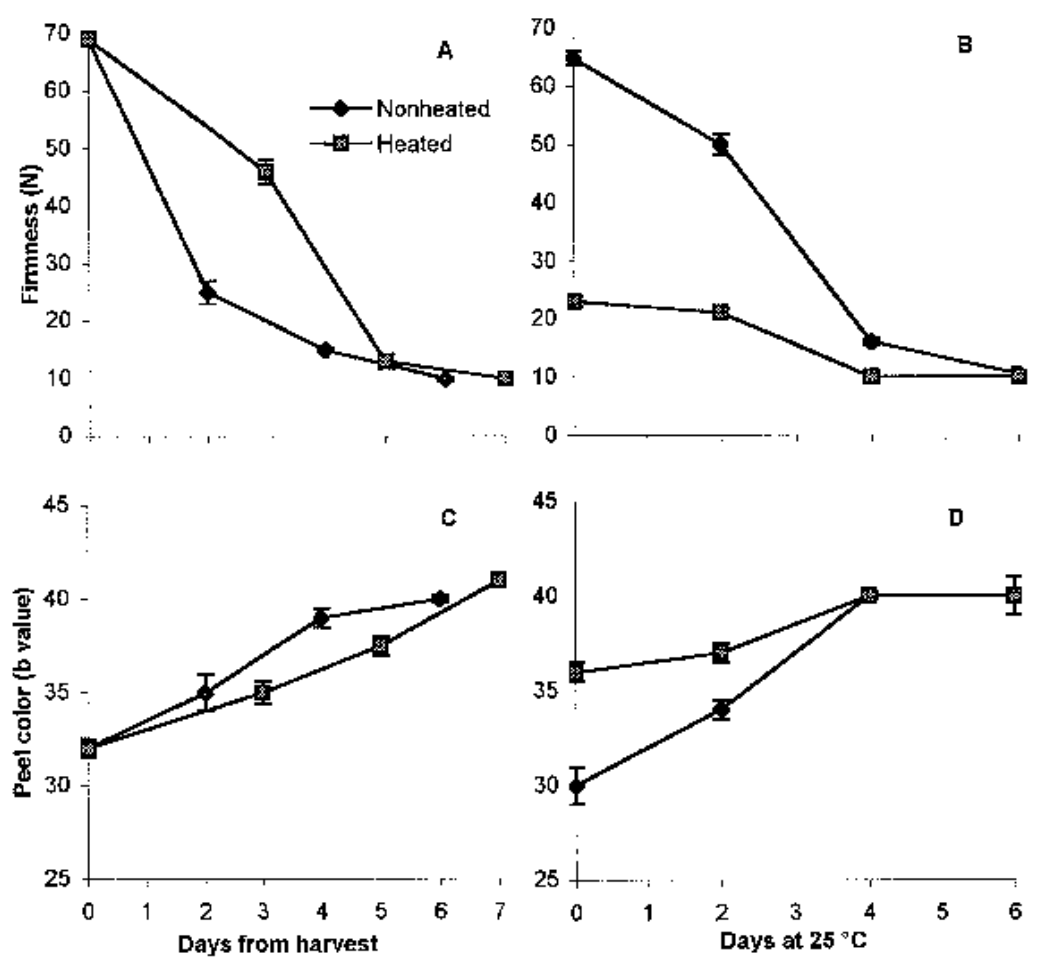

Fig. 2. Firmness expressed in Newtons of nonheated or heated $\left(38^{\circ} \mathrm{C}\right.$ for $\left.3 \mathrm{~d}\right)$ mango fruit $(\mathbf{A})$ placed at 25 ${ }^{\circ} \mathrm{C}$ or (B) first held for 3 weeks at $4{ }^{\circ} \mathrm{C}$ and then placed at $25^{\circ} \mathrm{C}$. Peel color (greater b value indicates yellower fruit) of nonheated or heated mango fruit $(\mathbf{C})$ placed at $25^{\circ} \mathrm{C}$ or $(\mathbf{D})$ first cold-stored and then placed at $25^{\circ} \mathrm{C}$. Vertical bars indicate standard deviation.
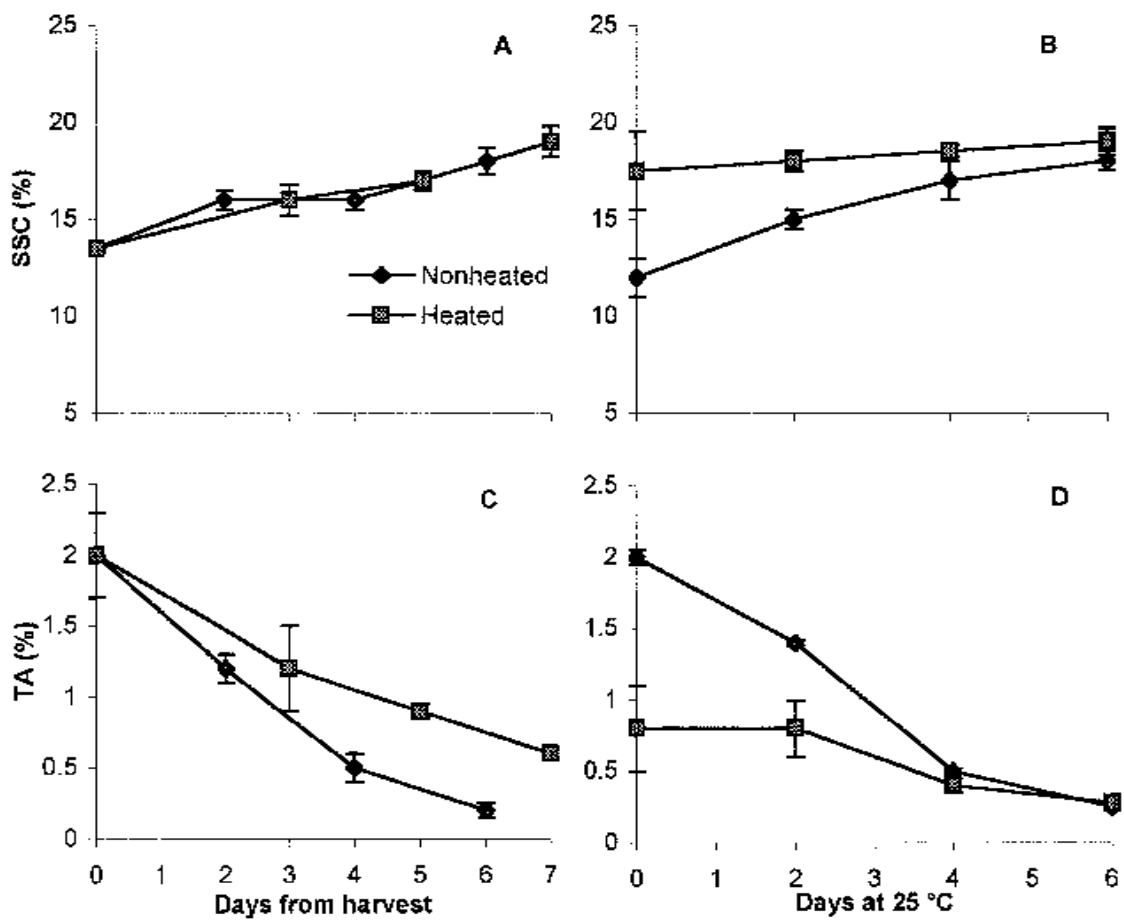

Fig. 3. Soluble solids content (SSC) of nonheated or heated $\left(38^{\circ} \mathrm{C}\right.$ for $3 \mathrm{~d}$ ) mango fruit (A) placed at $25^{\circ} \mathrm{C}$ or (B) first cold-stored and then placed at $25^{\circ} \mathrm{C}$. Titratable acidity (TA) of nonheated and heated fruit (C) placed at $25^{\circ} \mathrm{C}$ or (D) first cold-stored and then placed at $25^{\circ} \mathrm{C}$. Vertical bars indicate standard deviation. 
response to a postharvest heat treatment, and the temperatures in Thailand are higher than in Israel, where the previous studies were conducted. In those studies, the apples were harvested in the fall and the tomatoes from plastic houses in the winter. Fruit temperatures at the time of harvest were between 20 and $25^{\circ} \mathrm{C}$. A period at a moderately elevated temperature (such as $38^{\circ} \mathrm{C}$ ) can induce thermotolerance and allow tissue to withstand higher temperatures. Such thermotolerance may already have been induced in these tropical mangoes, and to achieve an effect they would need to be subjected to temperatures above $40{ }^{\circ} \mathrm{C}$.

During cold storage the heated fruit also continued to ripen, as evidenced by the decrease in firmness and TA and the increase in SSC. Again, this differs from other studies that showed a maintenance of ripening inhibition in heated fruit during storage and removal of this inhibition only upon transfer to ambient conditions (Lurie et al., 1996). However, since in this case no inhibition was conferred by the heat treatment, there was no inhibition to maintain in storage. The heated fruit ripened earlier, but eventually the nonheated fruit reached the same full ripeness.

Although the $38^{\circ} \mathrm{C}$ treatment did not have the effect on ripening that was expected from other studies, it did improve the quality of the fruit after low-temperature storage. There were lower levels of decay and chilling injury in heated fruit than in nonheated fruit, and no off-flavors in heated fruit. Decay by $C$. gloeosporioides was greatly reduced in the heated and stored fruit. Extended times at 38 ${ }^{\circ} \mathrm{C}$ can have an adverse effect on a number of pathogens, including Penicillium expansum (Link) Thom. on apples (Fallik et al., 1995), and Botrytis cinerea Pers.: Fr. on tomatoes (Fallik et al., 1993). Both spore germination and mycelial growth are inhibited at this temperature. Since many infections by $C$. gloeosporioides are quiescent, germination is not as important as the development of the fungus. Even when decay appeared on the heated fruit, the diameter of the affected area was less, indicating that although the heat treatment did not kill the fungus, the pathogen developed more slowly.

The development of CI was slower on heated and cold-stored mango fruit, as demonstrated first by McCollum et al. (1993). They also found that the SSC of heated fruit was higher in the cultivar they used ('Keitt'). In contrast with our study, they did not find that heating affected fruit softening or TA.

In conclusion, holding 'Nam Dok Mai' mango fruits for $3 \mathrm{~d}$ at $38^{\circ} \mathrm{C}$ enhanced fruit ripening during storage, so that the fruit were riper on removal from storage and reached the full ripe stage more quickly than did nonheated fruit. Heating the fruit before cold storage also decreased decay and CI and prevented the development of off-flavors.

\section{Literature Cited}

Fallik, E., S. Grinberg, M. Gambourg, J.D. Klein, and S. Lurie. 1995. Prestorage heat treatment reduces pathogenicity of Penicillium expansum in apple fruit. Plant Pathol. 45:92-97.

Fallik, E., J.D. Klein, S. Grinberg, E. Lomaniec, S. Lurie, and A. Lalazar. 1993. Effect of postharvest heat treatment of tomatoes on fruit ripening and decay caused by Botrytis cinerea. Plant Dis. 77:985-988.

Joyce, D.C. and A.J. Shorter. 1994. High-temperature conditioning reduces hot water treatment injury of 'Kensington Pride' mango fruit. HortScience 29:1047-1051.

Lay-Yee, M., S. Ball, S.K. Forbes, and A.B. Woolf. 1997. Hot water treatment for insect disinfestation and reduction of chilling sensitivity of 'Fuyu' persimmon. Postharv. Biol. Technol. 10:81-87.

Lizada, M.C.C., S. Kosiyachinada, and D.B. Mendoza 1984. Physiological disorders of mango, p. 68 74. In: D.B. Mendoza and R.B.H. Wills (eds.) Mango: Fruit development, postharvest physiology and marketing in ASEAN. ASEAN Food Handling Bur., Kuala Lumpur, Malaysia.

Lurie, S. 1998. Postharvest heat treatments. Postharv. Biol. Technol. 14:257-269.

Lurie, S., A. Handros, E. Fallik, and R. Shapira. 1996. Reversible inhibition of tomato fruit gene expression at high temperature. Plant Physiol. 110:1207-1214.

Lurie, S. and J.D. Klein. 1990. Heat treatment of ripening apples: Differential effects on physiology and biochemistry. Physiol. Plant. 78:181-186.

Lurie, S. and J.D. Klein. 1991. Acquisition of low temperature tolerance in tomatoes by exposure to high temperature stress. J. Amer. Soc. Hort. Sci. 116:1007-1012.

Lurie, S. and J.D. Klein. 1992. Ripening characteristics of tomatoes stored at 12 and $2{ }^{\circ} \mathrm{C}$ following a prestorage heat treatment. Scientia Hort. 51:5564.

McCollum, T.G., S. D' Aquino, and R.E. McDonald. 1993. Heat treatment inhibits mango chilling injury. HortScience 28:197-198.

Paull, R.E. 1990. Chilling injury of crops of tropical and subtropical origin, p. 17-36. In: C.Y. Wang (ed.). Chilling injury of horticultural crops. CRC Press, Boca Raton, Fla.

Woolf, A.B., S. Ball, K.J. Spooner, M. Lay-Yee, I.B. Ferguson, C.B. Watkins, A. Gunson, and S.K. Forbes. 1997. Reduction of chilling injury in the sweet persimmon 'Fuyu' during storage by dry air heat treatments. Postharv. Biol. Technol. 11:155-164.

Woolf, A.B. and M. Lay-Yee. 1997. Pretreatments at $38^{\circ} \mathrm{C}$ of 'Hass' avocado confer thermotolerance to $50^{\circ} \mathrm{C}$ hot water treatments. HortScience 32:705-708.

Woolf, A.B., C.B. Watkins, J.H. Bowen, M. LayYee, J.H. Maindonald, and I.B. Ferguson 1995. Reducing external chilling injury in stored 'Hass' avocados with dry heat treatment. J. Amer. Soc. Hort. Sci. 120:1050-1056. 